\title{
METODE COCHRANE-ORCUTT UNTUK MENGATASI AUTOKORELASI PADA ESTIMASI PARAMETER ORDINARY LEAST SQUARES
}

\author{
Ade Aprianto, Naomi Nessyana Debataraja, Nurfitri Imro'ah
}

\begin{abstract}
INTISARI
Autokorelasi merupakan salah satu pelanggaran asumsi di metode Ordinary Least Squares (OLS) yang terjadi pada pengamatan-pengamatan yang berbeda antar error. Salah satu metode yang digunakan untuk mendeteksi autokorelasi adalah dengan menggunakan uji Run. Jika terjadi autokorelasi, maka model regresi tidak memenuhi asumsi metode OLS. Salah satu cara untuk mengatasi autokorelasi adalah dengan menggunakan metode Cochrane-Orcutt. Tujuan penelitian ini yaitu mengatasi terjadinya autokorelasi pada model regresi dengan metode Cochrane-Orcutt, serta aplikasinya pada faktor-faktor yang mempengaruhi IPM di Indonesia Tahun 2015 dengan variabel bebas yang digunakan yaitu persentase rumah tangga memiliki akses terhadap air bersih, tingkat pengangguran terbuka (TPT) dan angka partisipasi sekolah jenjang pendidikan SMA. Metode Cochrane-Orcutt dilakukan dengan menghitung nilai $\hat{\rho}$ secara berulang, sehingga mendapatkan nilai $\hat{\rho}$ yang konvergen. Hasil penelitian menunjukkan bahwa model regresi terjadi autokorelasi yang dilakukan dengan uji Run yaitu nilai $R=10$ tidak berada pada nilai batas bawah dan batas atas sebesar 12,02 dan 22,92. Model regresi yang terjadi autokorelasi dilakukan perbaikan dengan metode Cochrane-Orcutt dengan mencari nilai $\hat{\rho}$ secara berulang dan diperoleh nilai $\hat{\rho}$ yang sudah konvergen yaitu 0,2305117948. Model regresi dilakukan uji Run kembali dengan nilai $R=13$ yaitu berada pada nilai batas bawah dan batas atas sebesar 11,94 $R \leq 23,04$ sehingga model tidak terjadi autokorelasi dan dapat disimpulkan bahwa metode CochraneOrcutt dapat mengatasi autokorelasi.
\end{abstract}

Kata kunci: Regresi, OLS, Autokorelasi, Cochrane-Orcutt

\section{PENDAHULUAN}

Autokorelasi merupakan salah satu pelanggaran terhadap asumsi pada metode OLS yang terjadi pada pengamatan-pengamatan yang berbeda antar error. Salah satu uji yang digunakan untuk mendeteksi autokorelasi pada model regresi adalah dengan uji Run. Uji Run memberikan kesimpulan yang lebih pasti dengan hanya ada dua kemungkinan saja yaitu terjadi autokorelasi atau tidak terjadi autokorelasi. Jika terjadi autokorelasi pada model regresi OLS, maka akan mengakibatkan penaksir parameter model regresi yang diperoleh menjadi tidak BLUE. Hal itu menyebabkan hasil estimasi pada pengujian parameter OLS menjadi tidak dapat digunakan untuk evaluasi hasil regresi [1]. Oleh karena itu perlu dilakukan suatu tindakan untuk mengatasi terjadinya autokorelasi. Metode untuk mengatasi autokorelasi yaitu Cochrane-Orcutt, Durbin Two-Step Procedure dan The Hildret-Lu.

Metode Cochrane-Orcutt merupakan salah satu metode yang dapat digunakan untuk mengatasi masalah autokorelasi pada model regresi. Metode Cochrane-Orcutt dilakukan dengan menghitung nilai $\hat{\rho}$ (koefisien autokorelasi) menggunakan nilai error pada model regresi. Untuk mendapatkan nilai $\hat{\rho}$ yang menjamin tidak terdapat masalah autokorelasi pada metode Cochrane-Orcutt, dalam mencari nilai $\hat{\rho}$ dilakukan secara berulang untuk mendapatkan nilai $\rho$ yang sudah konvergen [2].

Adapun tujuan pada penelitian ini yaitu mengatasi terjadinya autokorelasi pada model regresi dengan metode Cochrane-Orcutt serta aplikasinya pada faktor-faktor yang mempengaruhi IPM di Indonesia Tahun 2015. Data yang digunakan yaitu data Indeks Pembangunan Manusia (IPM) sebagai variabel terikat dengan persentase rumah tangga memiliki persentase rumah tangga memiliki akses terhadap air bersih, tingkat pengangguran terbuka, angka partisipasi sekolah jenjang pendidikan SMA sebagai variabel bebas pada 34 provinsi di Indonesia. 
Pada penelitian ini dilakukan studi literatur dengan mempelajari metode regresi, asumsi autokorelasi dan metode Cochrane-Orcutt. Data dilakukan analisis pada metode regresi untuk mendapatkan model regresi dari data dengan estimasi OLS. Selanjutnya dilakukan uji asumsi klasik yaitu uji normalitas, uji multikolinearitas, uji heterokedastisitas, uji autokorelasi. Uji autokorelasi dilakukan dengan menggunakan uji Run dari model regresi yang telah didapat untuk diketahui apakah data tersebut terjadi autokorelasi atau tidak. Penelitian ini data yang digunakan harus terjadi autokorelasi, jika tidak artinya data tersebut harus diganti dengan data baru yang mengandung autokorelasi. Selanjutnya data yang mengandung autokorelasi tersebut diperbaiki dengan menggunakan metode Cochrane-Orcutt. Tahapan selanjutnya dilakukan kembali pengecekan uji autokorelasi dengan uji Run. Jika model regresi tersebut sudah tidak terjadi autokorelasi maka langkah terakhir adalah dilakukan interpretasi.

\section{METODE ORDINARY LEAST SQUARES (OLS)}

Metode OLS merupakan salah satu metode yang sering digunakan untuk mengestimasi parameter regresi. OLS digunakan pada model regresi linear berganda untuk mengestimasi parameter regresi. Prinsip dasar dari metode OLS yakni bertujuan menemukan estimasi $\boldsymbol{\beta}$ pada Persamaan berikut:[3]

$$
\left[\begin{array}{c}
y_{1} \\
y_{2} \\
\vdots \\
\vdots \\
y_{n}
\end{array}\right]=\left[\begin{array}{ccccc}
1 & x_{11} & x_{12} & \cdots & x_{1 k} \\
1 & x_{21} & x_{22} & \cdots & x_{2 k} \\
\vdots & \vdots & \vdots & \vdots & \vdots \\
\vdots & \vdots & \vdots & \vdots & \vdots \\
1 & x_{n 1} & x_{n 2} & \cdots & x_{n k}
\end{array}\right]\left[\begin{array}{c}
\beta_{0} \\
\beta_{1} \\
\beta_{2} \\
\vdots \\
\vdots \\
\beta_{k}
\end{array}\right]+\left[\begin{array}{c}
\varepsilon_{1} \\
\varepsilon_{2} \\
\vdots \\
\vdots \\
\varepsilon_{n}
\end{array}\right]
$$

dan dalam bentuk notasi matriks adalah

$$
\boldsymbol{Y}=\mathbf{X} \boldsymbol{\beta}+\boldsymbol{\varepsilon}
$$

dengan $\boldsymbol{Y}$ merupakan vektor variabel respon berukuran $(n \times 1), \boldsymbol{X}$ merupakan matriks variabelvariabel prediktor berukuran $(n \times(k+1))$ yang diketahui; $\boldsymbol{\beta}$ merupakan vektor parameter regresi berukuran $((k+1) \times 1)$ dan $\boldsymbol{\varepsilon}$ merupakan vektor error yang berukuran $(n \times 1)$. Jumlah kuadrat error dapat dinyatakan dalam notasi matriks sebagai $\sum \varepsilon_{i}^{2}=\boldsymbol{\varepsilon}^{T} \boldsymbol{\varepsilon}$, sehingga diperoleh sebagai berikut.

$$
\begin{aligned}
\boldsymbol{\varepsilon}^{T} \boldsymbol{\varepsilon} & =(\boldsymbol{Y}-\boldsymbol{X} \boldsymbol{\beta})^{T}(\boldsymbol{Y}-\boldsymbol{X} \boldsymbol{\beta}) \\
& =\boldsymbol{Y}^{T} \boldsymbol{Y}-\boldsymbol{Y}^{T} \boldsymbol{X} \boldsymbol{\beta}-\left(\boldsymbol{Y}^{T} \boldsymbol{X} \boldsymbol{\beta}\right)^{T}+(\boldsymbol{X} \boldsymbol{\beta})^{T}(\boldsymbol{X} \boldsymbol{\beta}) \\
& =\boldsymbol{Y}^{T} \boldsymbol{Y}-2\left(\boldsymbol{Y}^{T} \boldsymbol{X} \boldsymbol{\beta}\right)^{T}+\boldsymbol{\beta}^{T} \boldsymbol{X}^{T} \boldsymbol{X} \boldsymbol{\beta} \\
& =\boldsymbol{Y}^{T} \boldsymbol{Y}-2 \boldsymbol{\beta}^{T} \boldsymbol{X}^{T} \boldsymbol{Y}+\boldsymbol{\beta}^{T} \boldsymbol{X}^{T} \boldsymbol{X} \boldsymbol{\beta}
\end{aligned}
$$

Untuk mendapatkan nilai minimum dari jumlah kuadrat error tersebut sama dengan nol, diperoleh:

$$
\begin{aligned}
\frac{\partial\left(\boldsymbol{\varepsilon}^{T} \boldsymbol{\varepsilon}\right)}{\partial \boldsymbol{\beta}} & =0 \\
\frac{\partial\left(\boldsymbol{Y}^{T} \boldsymbol{Y}-\boldsymbol{2} \boldsymbol{\beta}^{T} \boldsymbol{X}^{T} \boldsymbol{Y}+\boldsymbol{\beta}^{T} \boldsymbol{X}^{T} \boldsymbol{X} \boldsymbol{\beta}\right)}{\partial \boldsymbol{\beta}} & =0 \\
\left(\boldsymbol{X}^{T} \boldsymbol{X}\right) \boldsymbol{\beta}-\boldsymbol{X}^{T} \boldsymbol{Y} & =0 \\
\left(\boldsymbol{X}^{T} \boldsymbol{X}\right) \boldsymbol{\beta} & =\boldsymbol{X}^{T} \boldsymbol{Y} \\
\left(\boldsymbol{X}^{T} \boldsymbol{X}\right)^{-1}\left(\boldsymbol{X}^{T} \boldsymbol{X}\right) \boldsymbol{\beta} & =\left(\boldsymbol{X}^{T} \boldsymbol{X}\right)^{-1} \boldsymbol{X}^{T} \boldsymbol{Y} \\
\boldsymbol{I} \boldsymbol{\beta} & =\left(\boldsymbol{X}^{T} \boldsymbol{X}\right)^{-1} \boldsymbol{X}^{T} \boldsymbol{Y} \\
\boldsymbol{\beta} & =\left(\boldsymbol{X}^{T} \boldsymbol{X}\right)^{-1} \boldsymbol{X}^{T} \boldsymbol{Y}
\end{aligned}
$$


Maka diperoleh parameter penduga OLS yaitu:

$$
\boldsymbol{\beta}=\left(\boldsymbol{X}^{T} \boldsymbol{X}\right)^{-1} \boldsymbol{X}^{T} \boldsymbol{Y}
$$

\section{PENDETEKSIAN AUTOKORELASI DENGAN UJI RUN}

Uji Run digunakan untuk menguji antar residual terdapat autokorelasi atau tidak. Prinsip kerja Uji Run dengan melihat tanda nilai residual negatif (-) atau positif (+) tanpa memperhatikan nilainya seperti Gambar 1 berikut:[1]

$$
(+++++)(----)(+++)(--)
$$

\section{Gambar 1 Nilai Residual Positif dan Negatif}

Pada Gambar 1 diketahui bahwa ada 4 jumlah Run yang didapat dari 5 residual positif, diikuti oleh 4 residual negatif, diikuti oleh 3 residual positif dan diikuti 2 residual negatif sehingga ada 14 observasi. Untuk menghitungnya digunakan fungsi berikut:

$$
\begin{array}{r}
\text { Mean: } E(R)=\frac{2 N_{1} N_{2}}{N}+1 \\
\text { Variansi: } \sigma_{R}^{2}=\frac{2 N_{1} N_{2}\left(2 N_{1} N_{2}-N\right)}{(N)^{2}(N-1)}
\end{array}
$$

dimana $N$ adalah jumlah observasi $\left(N_{1}+N_{2}\right), N_{1}$ adalah jumlah residual yang bernilai positif, $N_{2}$ adalah jumlah residual yang bernilai negatif dan $R$ adalah jumlah $R u n$. Adapun pasangan hipotesis uji untuk uji Run adalah sebagai berikut:

$H_{0}$ : Tidak ada autokorelasi

$H_{1}$ : Ada autokorelasi

Dalam melakukan pengujian hipotesis, digunakan analisis interval kepercayaan dengan $\alpha=5 \%$ :

$$
E(R)-Z_{\alpha / 2} \sigma_{R} \leq R \leq E(R)+Z_{\alpha / 2} \sigma_{R}
$$

Dengan kesimpulan yaitu, apabila nilai $R$ berada diantara interval tersebut maka $H_{0}$ diterima sehingga disimpulkan tidak ada terjadi autokorelasi. Sedangkan jika nilai $R$ berada di luar interval maka $H_{0}$ ditolak.

\section{METODE COCHRANE-ORCUTT}

Metode Cochrane-Orcutt merupakan metode yang digunakan untuk perbaikan bila suatu model regresi ditemukan terjadi autokorelasi. Ketika struktur autokorelasi tidak diketahui, maka untuk mengetahui nilai $\hat{\rho}$ (koefisien autokorelasi) dapat ditentukan dengan menggunakan formula sebagai berikut:

$$
\hat{\rho}=\frac{\sum_{i}^{n} e_{i} e_{i-1}}{\sum_{i}^{n} e_{i-1}^{2}}, i=2,3,4 \ldots, n
$$

dimana $e_{i}$ adalah nilai error pada observasi ke- $i, e_{i-1}$ adalah nilai error pada observasi ke- $(i-1)$ dan $n$ adalah banyaknya observasi [2].

Pada metode ini autokorelasi dihilangkan secara bertahap dari bentuk yang paling sederhana sehingga autokorelasi dapat diatasi. Tahapan pada metode Cochrane-Orcutt sebagai berikut.

1. Menggunakan metode OLS untuk mendapatkan estimasi model regresi dan mendapatkan nilai error dari model regresi.

2. Meregresikan error ke-i dengan error ke- $(i-1)$ untuk mendapatkan nilai $\hat{\rho}$. Nilai koefisien autokorelasi dilambangkan dengan $\rho$ ada pada Persamaan (5).

3. Meregresikan nilai $\hat{\rho}$ pada persamaan berikut.

Sehingga diperoleh

$$
\begin{array}{r}
Y_{i}-\hat{\rho} Y_{i-1}=\beta_{0}-\hat{\rho} \beta_{0}+\beta_{i} X_{i}-\hat{\rho} \beta_{i} X_{i-1}+\hat{\rho} \varepsilon_{i}-\hat{\rho} \varepsilon_{i-1} \\
=\beta_{0}(1-\hat{\rho})+\beta_{i}\left(X_{i}-\hat{\rho} X_{i-1}\right)+\hat{\rho} \varepsilon_{i}-\hat{\rho} \varepsilon_{i-1}
\end{array}
$$

$$
Y_{i}^{*}=\beta_{0}^{*}+\beta_{i}^{*} X_{i}^{*}+\varepsilon_{i}^{*}
$$


Dimana $Y_{i}^{*}=Y_{i}-\hat{\rho} Y_{i-1}$

$\beta_{0}^{*}=\beta_{0}-\hat{\rho} \beta_{0}$

$X_{i}^{*}=X_{i}-\hat{\rho} X_{i-1}$

$\beta_{i}^{*}=\beta_{i}$

Pada langkah ini belum diketahui apakah nilai $\hat{\rho}$ yang diperoleh pada iterasi pertama merupakan nilai terbaik dalam mengatasi terjadinya autokorelasi. Nilai $\hat{\rho}$ ditransformasikan ke Persamaan (6) sehingga diperoleh nilai error dari model yang baru. Langkah ini perlu dilakukan secara berulang hingga diperoleh nilai $\hat{\rho}$ yang sudah bersifat konvergen [4].

\section{STUDI KASUS}

Studi kasus pada penelitian ini dilakukan pada data Indeks Pembangunan Manusia (IPM) sebagai variabel terikat $(Y)$ dengan Persentase Rumah Tangga Memiliki Akses terhadap Air Bersih $\left(X_{1}\right)$, Tingkat Pengangguran Terbuka $\left(X_{2}\right)$, Angka Partisipasi Sekolah Jenjang Pendidikan SMA $\left(X_{3}\right)$ sebagai variabel bebas pada data 34 provinsi di Indonesia Tahun 2015. Data tersebut merupakan data sekunder yang diperoleh dari Badan Pusat Statistik Indonesia (www.bps.go.id). Berikut adalah hasil statistik dekriptif untuk setiap variabel.

Tabel 1 Statistik Deskriptif

\begin{tabular}{cccccc}
\hline Variabel & $\mathrm{N}$ & Minimum & Maksimum & Rata-rata & Std. Deviasi \\
\hline$Y$ & 34 & 57,25 & 78,99 & 68,58 & 4,17 \\
$X_{1}$ & 34 & $41,08 \%$ & $93,40 \%$ & $68,62 \%$ & 11,04 \\
$X_{2}$ & 34 & $1,99 \%$ & $9,93 \%$ & $5,98 \%$ & 1,96 \\
$X_{3}$ & 34 & $61,96 \%$ & $86,78 \%$ & $73,08 \%$ & 6,08 \\
\hline
\end{tabular}

Pada Tabel 1 dapat diketahui bahwa data dari setiap variabel berjumlah 34. Nilai rata-rata untuk IPM di Indonesia tahun 2015 adalah 68,58, nilai rata-rata persentase rumah tangga memiliki akses terhadap air bersih di Indonesia tahun 2015 sebesar 68,62\%, nilai rata-rata tingkat pengangguran terbuka di Indonesia tahun 2015 sebesar 5,98\% dan nilai rata-rata angka partisipasi sekolah jenjang pendidikan SMA di Indonesia tahun 2015 sebesar 73,08\%. Nilai minimum, nilai maksimum dan standar deviasi pada variabel terikat dan variabel bebas dapat dilihat pada Tabel 1 .

Model regresi merupakan model yang didapat setelah dilakukan analisis pada data dengan dilakukan estimasi parameter menggunakan metode OLS sehingga didapat nilai koefisien dari masingmasing variabel. Berikut hasil yang diperoleh dari hasil analisis.

Tabel 2 Koefisien Model Regresi

\begin{tabular}{ccccccc}
\hline Model & Koefisien & $\begin{array}{c}\text { Standar } \\
\text { Error }\end{array}$ & $t_{\text {hitung }}$ & $F_{\text {hitung }}$ & $\begin{array}{c}R \text { - } \\
\text { Square }\end{array}$ & $\begin{array}{c}\text { Adjusted } \\
\text { R-Square }\end{array}$ \\
\hline Konstanta & 41,666 & 6,674 & 6,243 & 9,5 & 0,496 & 0,445 \\
$X_{1}$ & 0,221 & 0,052 & 4,251 & & & \\
$X_{2}$ & 0,241 & 0,279 & 0,864 & & & \\
$X_{3}$ & 0,141 & 0,095 & 1,480 & & & \\
\hline
\end{tabular}

Berdasarkan Tabel 2, diperoleh model regresi yaitu $\hat{Y}=41,666+0,221 X_{1}+0,241 X_{2}+0,141 X_{3}$. Nilai $F_{\text {hitung }}$ sebesar 9,5 lebih besar dari nilai $F_{(0,05 ; 3 ; 30)}$ sebesar 2,92 sehingga keputusan yang diambil yaitu tolak $H_{0}$ yang berarti terdapat hubungan linear antara variabel-variabel bebas dengan variabel terikat. Hubungan tersebut juga dapat dilihat pada nilai adjusted $R$-square sebesar 0,445. Artinya, variabel bebas mempengaruhi variabel terikat sebesar 44,5\%, sedangkan 55,5\% dipengaruhi oleh variabel lain. Nilai $t_{\text {hitung }}$ masing-masing variabel bebas adalah $X_{1}=4,251, X_{2}=0,864, X_{3}=1,480$ 
dan nilai $t_{\text {tabel }}=1,6973$. Nilai $t_{\text {hitung }}$ untuk variabel $X_{1}$ lebih besar dari $t_{\text {tabel }}$ artinya berpengaruh signifikan terhadap IPM. Nilai $t_{\text {hitung }}$ untuk variabel $X_{2}$ dan $X_{3}$ lebih kecil dari $t_{\text {tabel }}$ artinya tidak berpengaruh signifikan terhadap IPM.

Uji asumsi klasik adalah uji untuk mengetahui apakah model memenuhi asumsi atau tidak pada model regresi linear berganda. Adapun uji asumsi klasik yang akan diuji yaitu uji normalitas, uji multikolinearitas, uji autokorelasi dan uji heteroskedastisitas. Uji normalitas dilakukan dengan metode Kolmogorov-Smirnov. Berikut hasil pengujian yang dilakukan melalui uji Kolmogorov-Smirnov (KS) dengan hipotesis:

$H_{0}:$ Error berdistribusi normal

$H_{1}$ : Error tidak berdistribusi normal

Kriteria penerimaan keputusan adalah terima $\mathrm{H}_{0}$ jika $\mathrm{KS}_{(\alpha, \mathrm{n})}>\mathrm{KS}_{\text {hitung }}$ atau nilai $p$-value $>\alpha$. Hasil pengujian normalitas dapat dilihat pada Tabel 3 berikut ini.

Tabel 3 Uji Normalitas

\begin{tabular}{cc}
\hline$K S_{\text {hitung }}$ & $p-$ value \\
\hline 0,103 & 0,862 \\
\hline
\end{tabular}

Berdasarkan Tabel 3 dapat dilihat bahwa nilai $K S_{\text {hitung }}$ adalah 0,103 dan nilai $p$-value adalah 0,862. Nilai tabel Kolmogorov-Smirnov untuk $K S_{(0.05,34)}$ adalah 0,150. Dari Tabel 3 tersebut didapat nilai $K S_{(0.05,34)}>K S_{\text {hitung }}$ dan $p-$ value $>\alpha(\alpha=0,05)$, sehingga $H_{0}$ diterima dan dapat disimpulkan bahwa model regresi berdistribusi normal.

Uji multikolinearitas adalah untuk mengetahui adanya hubungan diantara variabel-variabel bebas dalam model regresi. Uji multikolinearitas dapat dilakukan dengan melihat nilai VIF pada hasil analisis yang telah dilakukan. Multikolinearitas tidak terjadi apabila nilai VIF lebih besar dari 10 pada masing-masing variabel bebas. Hasil dari analisis yang telah dilakukan yaitu nilai VIF untuk $X_{1}=$ 1,129, $X_{2}=1,021$ dan $X_{3}=1,145$. Berdasarkan hasil dari uji multikolinearitas menunjukkan nilai VIF lebih kecil dari 10, artinya bahwa setiap variabel bebas pada data tidak terjadi multikolinearitas.

Uji heterokedastisitas dilakukan untuk mengetahui apakah data terjadi heterokedastistas atau tidak. Uji heterokedastisitas dilakukan dengan uji Glejser, yaitu jika nilai signifikansi lebih besar dari nilai $a$ $(0,05)$ maka tidak terjadi heterokedastisitas, sebaliknya jika nilai signifikansi lebih kecil dari nilai $a$ $(0,05)$ maka terjadi heterokedastisitas. Hasil dari analisis yang telah dilakukan yaitu nilai signifikansi pada variabel $X_{1}=0,350, X_{2}=0,664$ dan $X_{3}=0,474$. Berdasarkan hasil uji heterokedastisitas dengan uji Glejser, nilai signifikansi dari masing-masing variabel lebih besar dari $a(0,05)$ artinya dapat disimpulkan bahwa data tidak terjadi heterokedastisitas.

Selanjutnya dilakukan uji autokorelasi, untuk mendeteksi autokorelasi dilakukan dengan menggunakan uji Run. Hipotesis untuk uji Run adalah sebagai berikut:

$H_{0}$ : Tidak ada Autokorelasi

$H_{1}$ : Ada Autokorelasi

Diketahui $R=10, N_{1}=20, N_{2}=14$ dan $N=34$. Berdasarkan hasil dari perhitungan yang telah dilakukan yaitu nilai $E(R)$ adalah 17,47 dan nilai $\sigma_{R}$ adalah 2,78. Dihasilkan nilai batas bawah dan batas atas untuk uji Run yaitu 12,02 dan 22, 92, sehingga dapat disimpulkan jumlah $R$ tidak berada pada interval artinya $H_{0}$ ditolak. Karena model regresi terjadi autokorelasi maka, perlu dilakukan tindakan untuk mengatasi model regresi yang terjadi autokorelasi.

Metode Cochrane-Orcutt merupakan salah satu alternatif pemecahan dalam permasalahan pada model regresi yang terjadi autokorelasi. Pada uji autokorelasi yang telah dilakukan dengan uji Run diketahui bahwa model regresi terjadi autokorelasi. Setelah diketahui bahwa model regresi terjadi 
autokorelasi, selanjutnya dilakukan tindakan untuk mengatasi autokorelasi dengan metode CochraneOrcutt. Berikut langkah-langkah dalam mengatasi autokorelasi dengan metode Cochrane-Orcutt.

Langkah awal pada metode Cochrane-Orcutt yaitu dengan mendapatkan nilai error dari hasil model regresi yang telah dilakukan dengan estimasi OLS. Berikut hasil dari nilai residual pada setiap observasi.

\begin{tabular}{cc}
\multicolumn{2}{c}{ Tabel 4 Nilai Error } \\
\hline No & Nilai Error \\
\hline 1 & 0,378 \\
2 & $-0,305$ \\
3 & 0,303 \\
$\vdots$ & $\vdots$ \\
34 & $-5,444$ \\
\hline
\end{tabular}

Pada Tabel 4 diketahui nilai error model regresi dari observasi ke-1 hingga ke-34. Kemudian nilai error tersebut disubstitusikan ke Persamaan (5) digunakan untuk mendapatkan nilai $\hat{\rho}$. Nilai $\rho$ yang didapat di transformasikan ke Persamaan (6) untuk dihasilkan model regresi yang baru, kemudian dilakukan pengulangan dalam mendapatkan nilai $\rho$ hingga konvergen. Berikut hasil nilai $\hat{\rho}$ yang diperoleh.

Tabel 5 Nilai $\widehat{\rho}$

\begin{tabular}{cc}
\hline Iterasi & $\hat{\rho}$ \\
\hline 1 & 0,4043519430 \\
2 & 0,0663544850 \\
3 & 0,3688328901 \\
$\vdots$ & $\vdots$ \\
153 & 0,2305117948 \\
154 & 0,2305117948 \\
\hline
\end{tabular}

Pada Tabel 5 diketahui hasil dari nilai $\hat{\rho}$, pada iterasi pertama belum diketahui apakah nilai $\hat{\rho}$ tersebut sudah merupakan nilai terbaik atau tidak. Nilai $\hat{\rho}$ yang dihasilkan pada iterasi pertama yaitu 0,4043519430, sehingga diperlukan pengulangan pada nilai $\hat{\rho}$ untuk memperoleh nilai $\hat{\rho}$ sudah konvergen. Selanjutnya dilakukan iterasi kedua sampai seterusnya hingga diperoleh pada analisis yang telah dilakukan nilai $\hat{\rho}$ yang terbaik adalah pada iterasi ke-153 yaitu 0,2305117948 .

Data yang telah ditransformasi dilakukan uji autokorelasi kembali untuk diketahui bahwa model regresi sudah tidak terjadi autokorelasi. Berikut hasil uji autokorelasi dengan data yang sudah dilakukan perbaikan dengan metode Cochrane-Orcutt. Selanjutnya dilakukan Uji Autokorelasi kembali untuk mendeteksi autokorelasi yang dilakukan dengan menggunakan Uji Run. Hipotesis untuk uji Run adalah sebagai berikut:

$H_{0}$ : Tidak terjadi Autokorelasi

$H_{1}$ : Terjadi Autokorelasi

Diketahui $R=13, N_{1}=17, N_{2}=16$ dan $N=33$. Berdasarkan hasil dari perhitungan yang telah dilakukan yaitu nilai $E(R)$ adalah 17,49 dan nilai $\sigma_{R}$ adalah 2,83 . Nilai batas bawah dan batas atas untuk uji Run yaitu 11,94 dan 23,04. Kesimpulan dari hasil uji Run dengan jumlah $R$ yang berada pada interval 11,94 $\leq R \leq 23,04$ artinya $H_{0}$ diterima dan model regresi tidak terjadi autokorelasi.

Kemudian dilakukan interpretasi model regersi dengan uji- $F$ dan uji- $t$ untuk mengetahui pengaruh dari variabel bebas terhdapat variabel terikat. Uji- $F$ yang dilakukan adalah pada model regresi yang telah dilakukan perbaikan autokorelasi dengan metode Cochrane-Orcutt. Berikut hasil uji-F yang telah dilakukan. 
Tabel 6 Uji- $F$

\begin{tabular}{cccccc}
\hline $\begin{array}{c}\text { Sumber } \\
\text { Keragaman }\end{array}$ & $\begin{array}{c}\text { Derajat } \\
\text { Independen }\end{array}$ & $\mathrm{F}_{\text {hitung }}$ & $F_{(0,05 ; 3 ; 29)}$ & $R$-Square & $\begin{array}{c}\text { Adjusted } \\
R \text {-Square }\end{array}$ \\
\hline Regresi & 3 & 9,5 & 2,93 & 0,496 & 0,444 \\
Galat & 29 & & & & \\
Total & 32 & & & & \\
\hline
\end{tabular}

Berdasarkan Tabel 6 diperoleh nilai $F_{\text {hitung }}$ sebesar 9,5 dengan taraf signifikansi sebesar 0,05 diperoleh nilai $F_{(0,05 ; 3 ; 29)}$ sebesar 2,93 sehingga keputusan yang diambil yaitu tolak $H_{0}$ yang berarti terdapat hubungan linear antara variabel-variabel bebas dengan variabel terikat. Hubungan tersebut juga dapat dilihat pada nilai adjusted $R$-square sebesar 0,444 artinya, variabel bebas mempengaruhi variabel terikat sebesar 44,4\%, sedangkan 55,6\% dipengaruhi oleh variabel lain.

Selanjutnya dilakukan uji- $t$ yang digunakan untuk menguji dari masing masing variabel bebas berpengaruh terhadap variabel terikat. Berikut hasil dari uji- $t$ yang telah dilakukan.

Tabel 7 Uji- $t$

\begin{tabular}{ccccc}
\hline Variabel & Koefisien & Standar Error & $\left|t_{\text {hitung }}\right|$ & Kesimpulan \\
\hline Konstanta & 31,546 & 4,831 & 6,530 & Signifikan \\
$X_{1}$ & 0,195 & 0,052 & 3,697 & Signifikan \\
$X_{2}$ & 0,222 & 0,259 & 0,858 & Tidak Signifikan \\
$X_{3}$ & 0,175 & 0,089 & 1,964 & Signifikan \\
\hline
\end{tabular}

Berdasarkan Tabel 7 diperoleh model regresi yaitu:

$$
\hat{Y}=31,546+0,195 X_{1}+0,222 X_{2}+0,175 X_{3}
$$

Dari model dapat dijelaskan bahwa pada variabel $X_{1}$ yaitu dengan bertambahnya persentase rumah tangga memiliki akses terhadap air bersih akan meningkatkan IPM sebesar 19,5\% dan dapat diketahui dari nilai $t_{\text {hitung }}$ sebesar 3,697 lebih besar dari nilai $t_{(0,05 ; 30)}=1,6991$ artinya persentase rumah tangga memiliki akses terhadap air bersih berpengaruh signifikan terhadap IPM. Pada variabel $X_{2}$ dijelaskan bahwa dengan bertambahnya tingkat pengangguran terbuka akan meningkatkan IPM sebesar 22,2\% dan dapat diketahui dari nilai $t_{\text {hitung }}$ sebesar 0,858 lebih kecil dari nilai $t_{(0,05 ; 30)}=1,6991$ artinya tingkat pengangguran terbuka tidak berpengaruh signifikan terhadap IPM, karena dengan meningkatnya pengangguran artinya tidak dapat meningkatkan IPM. Pada variabel $X_{3}$ dijelaskan bahwa dengan bertambahnya angka partisipasi sekolah jenjang pendidikan SMA akan meningkatkan IPM sebesar 17,5\% dan dapat diketahui dari nilai $t_{\text {hitung }}$ sebesar 1,964 lebih besar dari nilai $t_{(0,05 ; 30)}=1,6991$ artinya angka partisipasi sekolah jenjang pendidikan SMA berpengaruh signifikan terhadap IPM.

\section{KESIMPULAN}

Berdasarkan studi kasus yang telah dilakukan pada faktor-faktor yang mempengaruhi IPM di Indonesia tahun 2015, maka dapat disimpulkan bahwa metode Cochrane-Orcutt dapat mengatasi autokorelasi pada model regresi. Hasil penelitian menunjukkan bahwa diperoleh nilai $\rho$ yang sudah konvergen dengan metode Cochrane-Orcutt yaitu pada iterasi ke-153 dengan nilai $\rho=0,2305117948$. Nilai $\rho$ konvergen yang sudah ditransformasikan, dilakukan pengujian autokorelasi kembali dengan uji Run, sehingga dihasilkan model regresi sudah tidak terjadi masalah autokorelasi.

\section{DAFTAR PUSTAKA}

[1]. Gujarati, D.N., Basic Econometrics, Fourth Edition, McGraw-Hill/Irwin, New York, 2003. 
[2]. Sumodiningrat, G., Ekonometrika Pengantar, BPFE Yogyakarta, Yogyakarta, 1994.

[3]. Gujarati, D.N., Dasar-dasar Ekonometrika I alih bahasa Sumarno Zain, Salemba Empat, Jakarta, 2010.

[4]. Tinungki, G.M., Metode Pendeteksian Autokorelasi Murni Dan Autokorelasi Tidak Murni, Jurnal Matematika Statistika dan Komputasi, 2016, 13(1): 46-54.

[5]. Fathurahman, M., Metode Cochrane Orcutt Untuk Mengatasi Autokorelasi Pada Regresi Ordinary Least Squares, Jurnal Eksponensial, 2012, 3(1).

ADE APRIANTO

NAOMI NESSYANA DEBATARAJA

NURFITRI IMRO’AH
: Jurusan Matematika FMIPA UNTAN, Pontianak adeaprianto100496@gmail.com

Jurusan Matematika FMIPA UNTAN, Pontianak naominessyana@math.untan.ac.id : Jurusan Matematika FMIPA UNTAN, Pontianak nurfitriimroah@math.untan.ac.id 